\title{
Maintaining the Value of a Midwestern Community College in Kansas from External Stakeholders' Perspectives and Recommendations
}

\author{
Main Author \\ Mustafa, Mohammad B. * \\ mohammad.mustafa@ju.ac.ae \\ (Jumeira University) \\ Goodvin, Sharon Bever \\ sharon.goodvin@wichita.edu \\ (Wichita State University \\ Eubank, Heather \\ Heubank@wcsks.com \\ (Head of Wichita Collegiate Lower School \\ Watkins, Mark Charles Henry \\ markw@labette.edu \\ (Labette County Community College) \\ Jaradat, Maram \\ maram.jaradat@aau.ac.ae \\ (Al Ain University of Science and University) \\ Bakken, Linda \\ linda.bakken@wichita.edu \\ (Emeritus professor at Wichita State University) \\ Rathbun, Shelia E. \\ Srathbun@usd266.com \\ (Wichita Public Schools, USD 266) \\ Stucky, Janis \\ Jstucky@usd259.net \\ (Wichita Public Schools, USD 259) \\ * Corresponding author.
}

\begin{abstract}
In 2002, the Higher Learning Commission, a regional accrediting agency in the US, placed the community college in this study on academic probation for several criteria and many residents of the community believed that closing doors was the best option for addressing these concerns. This study is designed to ascertain data from external stakeholders of the community college regarding their current perceived value of the community college and suggestions about moving from the present to the future. The main question of the study is: What are external stakeholders' perceptions of the value of the college to the service area? This qualitative approach is used consisting of interviews, focus groups, surveys, and document review to triangulate stakeholder perspectives. Participants included 176 high school seniors from different counties, four counselors, and four focus groups. The findings from the data are presented in this study are planned to be used by community college officials to incorporate into their strategic plans. They showed that the college needs to consider the value that it brings to the service area including economic benefits, specifically community support; accessibility; and cost of tuition.
\end{abstract}

Keywords: stakeholders; community college; value; perspectives and recommendations 


\section{Introduction}

Since the founding of Joliet Junior College in 1901, America's dependence on twoyear community colleges has continued to grow. Presidents Truman (Brubacher \& Rudy, 1958), Johnson (Public papers of the presidents of the United States: Lyndon B. Johnson, 1966), Nixon (Public papers of the Presidents of the United States: Richard Nixon, 1971), Clinton (Clinton, 1998), Bush (Evelyn, 2004), and most recently Obama (Lewin, 2009) declared public support for the community college as a major contributor towards the democratization of America. More students are attending community colleges than ever before. In fall 2015, 38 percent of undergraduate students attended public and private twoyear colleges. Of full-time undergraduates, 24 percent attended community colleges (NCES, Enrollment and Employees in Postsecondary Institutions, 2015).

Among all students who completed a degree at a four-year college in 2015-16, 49 percent had enrolled at a two-year college in the previous 10 years, including high school students dual enrolled in community college courses (National Student Clearinghouse Research Center, 2017). In fall 2015, nearly 6.3 million students were enrolled in public, two-year colleges. About 2.3 million were full-time students and nearly 4 million were parttime. About 6.9 million students were enrolled in all two-year and less-than-two-year colleges, public and private, down from 7.2 million in fall 2014 (NCES, Enrollment and Employees in Postsecondary Institutions, Fall 2015 and Fall 2014). This is especially relevant during economic recessions when employers lay off unessential workers who return to post-secondary institutions to continue their education. Today, many people are struggling to hold onto jobs as the nation's unemployment rate has risen in September of 2009 to $9.8 \%$ (Bureau of Labor Statistics, 2009). Increasing enrollments and decreasing state funding place enormous pressures on community college officials to fulfill their mission. Under these circumstances, the president of a mid-west community college is interested in identifying the public's perception of the services the community college provides.

In the past, community colleges have been perceived by communities as "last chance colleges" for those with no funds and with little working-class skill. One of the most distinctive features of the American education system is that it offers all students, regardless 
of grade point average (GPA), multiple chances to succeed (Brint \& Karabel, 1989; Palmer, 2000; Shaw \& Jacobs, 2003). Today, community colleges are reexamining their missions and goals as a result of fiscal woes, fluctuations in enrollment numbers, and community needs for skilled workers (Purvis, 1995). Palmer (2000) indicates community colleges are becoming valued educational centers in communities to gain technical skills, developmental education, as well as personal enrichment. Community colleges often emphasize the importance of public expectations since their financial support depends on their communities' perceptions and support.

The perception of the community college by local townspeople is changing. Community colleges are meeting the needs of taxpayers and responding to the needs for a trained and literate work force (Badolato, 2010; Purvis, 1995). Community colleges are fostering relationships with business and industries in order to train capable and competent workers. Part of the community college's innovative character is that it provides both academic and vocational programs within the same institution (Brint \& Karabel, 1989). A more recent development between community colleges and local high schools has been the development of dual credit courses wherein high school students can take high school courses with college curriculum and receive both high school and college credit. By implementing college courses schools and colleges are both improving the success of low-income high school students and others with low educational attainment (The early college success story, 2010).

\section{Purpose of the Study and Research Questions}

In 2002, the Higher Learning Commission, a regional accrediting agency, placed the community college under the study on academic probation for several criteria (e.g., inadequate assessment system, the decision-making processes of the board, financial issues). Many residents of the community believed that closing doors was the best option for addressing these concerns. Taxpayers did not understand the college's value to the community and questioned whether their tax dollars were being used wisely to improve the community at large. A new college president was hired in 2003. Since that time, the college has worked to improve its academic reputation as well as its perceived value to the service area. Since that time, the college has become the fastest growing community college in the 
state of Kansas. The president attributes these gains to several factors including adding academic programs, maintaining high standards for graduates, and giving the community "what they want, when they want it." These changes have led to the perception by college administration that the community now supports the college and is satisfied with the direction in which the college is moving.

The president expressed a concern that the institution's progress remains relevant to the needs of the stakeholders. Through the strategic planning process, significant data have been collected on the perceptions of internal stakeholders; however, very little data are available on the perceptions of those outside of the community college. Ultimately, questions will be derived which may help guide community college leadership to move the institution towards the desired outcome especially when the college relies heavily on property tax-based funding which is provided by the residents of the county. Accordingly, understanding the perspective of these external stakeholders regarding how they value the college's role in the community is a central theme to this study.

This study focused on the perspectives of external stakeholders regarding the necessary modifications needed for the community college to move towards providing a higher level of service. A qualitative research approach is used consisting of interviews, focus groups, survey, and document review to triangulate stakeholder perspectives.

\section{Research Questions}

The study is intended to answer the following two questions:

1. What are external stakeholders' perceptions of the value of the college to the service area?

2. What recommendations do the external stakeholders have for the college to achieve this role? 


\section{Theoretical Framework}

Theories of organizational culture served as the mega framework for this study with a specific focus on organizational identity and the assumptions of an inviting culture.

Organizational identity. An organization's identity is defined by the culture it provides in the community (Anafara \& Mertz, 2006). The community's perceptions of the value provided by a community college and how it fits with the needs of the time are critical for a positive identity. A synthesis exists between the value of the individual in creating the whole of society, and in turn an organization's identity. The incorporation of attitudes serves as the impressions that are formed in developing expectations and guidelines for behavior and in identity formation in an organization (Cooley, 1902; Goffman, 1959; Mead, 1934). An organization's identity represents the collage of experiences and expectations of those who are involved with it and the various perspectives and motives brought with them. An organization's identity is important in order to recruit and retain students and bring a positive message to the community (Hatch \& Schultz, 2004). From the perspective of the community college the process of identification can be complicated because neither the individual nor the organization has a single identity, nor do they have consistency among the attributes. The focus of the organization's identity can change depending on the context of the information provided (Anafara \& Mertz, 2006).

Invitational theory. Invitational theory focuses on the relationship between students' perceptions of their culture and their subsequent behavior. In order for students to enroll in a specific institution their perceptions of the culture must fit with individual needs. Invitational theory provides a framework for determining parts of the culture that are inviting or disinviting to students. Inviting cultures provide elements of trust, respect, intentionality, and optimism (Purkey, 1992). Coupled with Identity theory, a person identifies with an inviting environment that brings a positive atmosphere to a successful future. The remainder of the literature will review the history of community colleges and their role in providing value and identity to the community as well as for students. 


\section{Research Design and Methodology}

A qualitative research approach is chosen for this because of the nature of the research problem and the questions being asked. This method offers a means of investigating complex social units with multiple variables of potential importance in understanding the phenomenon (Merriam, 1998). Research was conducted at multiple sites within communities of the service area. This provided for some diversity in the sites selected as well as in the participants interviewed. According to Merriam (1998), the strategy of including multiple sites enhances the external validity and generalizability of the findings.

Participants. Study participants were chosen from external stakeholders in the County service area. Purposeful sampling was used for the study to purposefully inform an understanding of the research problem and central phenomenon in the study (Cresswell, et al., 2003). For the purpose of this study, participants included 176 high school seniors. Approximately $50 \%$ of the high school seniors in these schools participated in the study. All participants 18 years or older were required to sign a consent form prior to participation in data collection. Students under 18 years of age were required to have a consent form signed by their parent/guardian as well an assent form. Four counselors were interviewed and four focus groups were conducted with community member representatives.

Data Collection Strategies. The methods of data collection included surveys of high school seniors, individual interviews of high school counselors, focus groups of community members, and a review of documents. Multiple researchers conducted the research, strengthening the internal validity of the study. Data collections consisted of observation of patterns of action, verbal and non-verbal interaction between members as well as between the subjects and researcher and his/her information.

Surveys. Surveys were administered to high school seniors in the five high schools in the service area. They were conducted during the normal school day by members of the research team. By conducting the survey on-site with the participants, the researchers were able to assure a high level of participation. 
Focus groups. The research team conducted four focus groups with six to eight community members. The purpose of the focus groups was to listen to the participants and gather information. The focus groups were audio recorded for transcribing purposes.

Personal interviews. The research team conducted personal interviews with four high school counselors. These counselors were chosen because of the close proximity of their schools to the community college nearby. Participation in the interviews was voluntary. An interview guide was designed to ensure that the same information was requested from each interviewee. This provided an outline for more systematic and comprehensive data gathering and kept the interactions in focus. Upon granted permission from each participant, the interviews were audio recorded to aid in transcription.

Document review. A review of the documents from the college administration that related to the strategic plan was conducted by the researchers. This information provided invaluable data for the research team in the data analysis process.

Trustworthiness of the Data. Multiple researchers reviewed the transcripts from each focus group and counselor interviews to ensure objectivity of analysis. All records and data are maintained in a central location for audit purposes.

\section{Findings and Discussion of Findings}

Two major themes emerged from the raw data when analyzed: value to the service area, and educational programming. These two themes provided a framework for answering the two research questions.

\section{Value to the Service Area}

The first theme directly responded to the first research question: "What are stakeholders' perceptions of the value of the college to the service area?" Almost half of the responses from participants indicated a positive perspective regarding the college's value to the service area. The service area is being defined as the communities directly impacted by the College either through payment of required taxes due to their location or the communities 
with close proximity to one of the college campuses although not located within the same county. Many shared that a host community could have an advantage over other communities in developing a deeper relationship with the college through easier access to facilities and increased interaction with the community. One participant stated it this way,

". . . another thing they have acquired since the president has been here is a good communication with the neighborhood. The college seemed to be a separate entity of almost something other than the community. She along with the rest of the administration have made it a part of the city."

The idea of the college being part of the community was different from how several nonhosting communities perceived their relationship with it. "The only time I see them is when the baseball team comes and asks for a donation," observed one participant. Non-hosting communities felt that they were not part of the college scope of concern and that they did not have a relationship with the college. Deeper study indicated that within the theme (value to the service area) were three categories: (a) Economic benefits, specifically community support; (b) accessibility; and (c) tuition costs.

\section{Economic Benefit and Community Support}

In terms of economic benefits, most responses were concerned with community support and were mostly positive in nature. Several participants recognized the positive image the college brought to the neighborhood. One participant shared, "[the college] brings a positive image to our community." Another participant recognized the positive connection with the community in this way, "They are not only involved with the college students but they do outside activities for the community that are magnificent ... so, I see the positive image reflected in a lot of areas." Still another stated,

"I think this community involvement is a huge thing to continue, and continue to grow. Because I don't think that I am paying for nothing. Even though I may not reap the benefits right now ... I feel that they promote in the area."

These positive connections with the community and the ability to bring a positive image to the hosting communities were a common theme throughout the comments regarding community support. 
Another economic benefit cited by several participants is that of bringing in people to attend college here who might remain in the area following graduation. "Another thing too that we may overlook, is that the college brings people in for college, but that doesn't always mean they move away. They may stay and it helps build our community if they plant here," praised one participant. Many believe the community college brings value to the community through job opportunities. Positive comments were made about the jobs students can get in the area after attending the college and the jobs the college brings to the community in general. "I think it is a benefit to the county for the fact [that] it does provide a lot of jobs to the area," stated a participant from the county. The idea that jobs are brought to the service area due to the location of the college campuses was supported by participants in both hosting and non-hosting communities. This participant summed it up this way,

"As for value ... taxes and so forth you are going to pay them regardless. We just hope they use it wisely. I think they really have. I think in the last 3 or 4 years they have changed quite a bit. I personally am more satisfied with them than I was."

Overall, participants were more satisfied with the economic benefit provided by the college in recent years over the perception of benefits in years past.

Although most of the comments regarding economic benefits were positive, a few negative comments were made. These comments walk the line between economic value and educational programming which will be discussed later. However, some participants felt that if more technical courses were offered it would benefit the community. "There is a tremendous need in this community, to this whole entire region, for technical education," observed one participant. Another participant commented about the need for more community oriented courses which might help some residents feel they are getting the most from their tax money. He stated, "Offer more community classes. It sounds that there is an interest in computer classes, business, ceramic, painting, and some training for ... employees." the college's ability to offer more courses geared toward the community and technical education was seen as a significant need by some participants for positive perceptions to increase. 


\section{Accessibility of the College to the Communities}

In the area of accessibility, both positive and negative statements were made. These statements were markedly dependent on whether or not the participant was from a hosting or non-hosting community. For example, participants from the hosting communities felt that the accessibility of the college and its programs was very good. A participant explained by saying, "We have a school right here in our community. We don't even have to have kids travel anywhere." A participant explained it in this way, "I think it's really something that's really good for our kids 'because they don't really have to leave town. I'm really pleased with that." Another participant recognized how the accessibility was reaching the older population in the community. He stated,

"One of the problems the community college has had in the past is that people over here are throwing darts at the community college, sometimes that's the older set, saying we don't need that because it costs more money in taxes. But because we can draw them in, they can feel they are getting something for their taxes. You haven't heard as much complaining. They also have the lifelong learning where they can take classes for free. So, they are getting benefit for their tax dollars."

There has been the perception that taxpaying constituents were not realizing a benefit from paying the taxes until the college began offering the facilities to members of the community. Allowing the community to use the college campus for meetings and providing opportunities for community members to take courses and stay informed rose to the top as the main reasons hosting communities are pleased with accessibility of the college.

On the other hand, non-hosting communities had some negative comments primarily due to the fact that the campus was not located in the community. A participant shared, "When it comes to geographical location a lot of students have gone to ... another community college ... so it's a little bit negative geographically to the College." Several participants expressed the fact many of the high school graduates want a new experience away from the county. This was not shared as a judgment of the college but simply a geographical challenge. A community member suggested that for some students in the area, it is too close to home. "It's probably the negative that they get because they're in town. The kids are used to [the college] and they're graduating from high school and I think that they're ... wanting a new 
experience." Another participant viewed it in this way, "That's probably the only negative about [the college] being here is that our kids look at it as kind of a 'Yeah, if everything else fails, I'll go to it." However, student survey data indicated that most students viewed location as a positive rather than a negative.

\section{Cost of Tuition}

Tuition costs were the third area addressed in terms of value to the service area. Many of the comments were positive and reflected the communities' appreciation for affordable education as compared to a four-year university. A participant stated, "I think you're gonna see more of our kids going to junior colleges as the prices are rising so dramatically for fouryear universities." Another participant observed, "With the economy the way that it is, the affordability plays an even bigger part." Student survey data overwhelmingly indicated that students consider cost as their number one reason for attending the college. Overall, the participants supported the lower cost tuition offered by the college and expressed value for having this option available to community members and students.

The topic of cost came up frequently during the focus groups and often centered on the need to charge fees for use of the facilities. There were comments regarding the unfairness of services provided by the community college which are not paid by the user of the service, but by others in the form of tax support. Several participants felt fees were not assessed enough for community members to use the equipment and facilities. "I think there ought to be a fee ... if they are going to use the facility. Because somewhere you're going to have to subsidize those people that are utilizing it," explained a participant from the county. These fees would help support programs the community wants to see continued or implemented such as computer courses, woodworking, etc. In contrast, other sentiments were reflected. One participant stated,

"While the tuition is relatively inexpensive, it bothers me that I have to pay computer fees and student union fees and all of these other fees if I am just wanting to take one class. I don't mind paying tuition but maybe we could have a different fee structure for those community members taking a class."

A participant suggested, "you could make it fairly nominal, a sliding fee or something that would be appropriate." The idea of differentiating fees for how and when the facilities at the 
college are used as well as which courses are taken was a common idea among participants from several communities. (See Table 1 for summary of value to the service area)

Table 1

Participants' Perceptions of the College Value to the Service Area

\begin{tabular}{|c|c|c|c|}
\hline Categories & Main Aspects & $+-0^{1}$ & Host/Non-host \\
\hline \multirow[t]{2}{*}{$\begin{array}{l}\text { Value to the } \\
\text { Service Area }\end{array}$} & $\begin{array}{l}\text { - Greatest contributors to the positive aspect were } \\
\text { participants from Two Areas }\end{array}$ & + & $\mathrm{H}$ \\
\hline & $\begin{array}{l}\text { - Some communities they were not in the college } \\
\text { scope of concern }\end{array}$ & - & $\mathrm{NH}$ \\
\hline \multirow[t]{4}{*}{$\begin{array}{l}\text { Economic } \\
\text { Benefit }\end{array}$} & $\begin{array}{l}\text { The college brings a positive image to the } \\
\text { community }\end{array}$ & + & $\mathrm{H}$ \\
\hline & $\begin{array}{l}\text { The college brings people in from outside the } \\
\text { community who may stay to reside }\end{array}$ & + & $\mathrm{H}$ \\
\hline & - The college provides job opportunities to the area & + & $\mathrm{H}$ \\
\hline & $\begin{array}{l}\text { - The college needs to broaden educational } \\
\text { coursework }\end{array}$ & - & $\mathrm{H}$ \\
\hline \multirow[t]{4}{*}{ Accessibility } & $\begin{array}{l}\text { Accessibility of the college and its programs was } \\
\text { very good }\end{array}$ & + & $\mathrm{H}$ \\
\hline & Community appreciated use of facilities & + & $\mathrm{H}$ \\
\hline & $\begin{array}{l}\text { High school student often attends another college } \\
\text { Community College due to proximity }\end{array}$ & - & NH \\
\hline & May be too close to home for some students & - & $\mathrm{H}$ and $\mathrm{NH}$ \\
\hline \multirow[t]{3}{*}{$\begin{array}{l}\text { Cost of } \\
\text { Tuition }\end{array}$} & $\begin{array}{l}\text { Communities appreciated the affordability of } \\
\text { courses at the college }\end{array}$ & + & $\mathrm{H}$ and $\mathrm{NH}$ \\
\hline & $\begin{array}{l}\text { Fees should be assessed to those community } \\
\text { members using the facilities who are not taxpayers }\end{array}$ & - & $\mathrm{H}$ and $\mathrm{NH}$ \\
\hline & $\begin{array}{l}\text { Differentiated fee scale for community members } \\
\text { needed so they do not have to pay student union } \\
\text { fees, computer fees, etc. }\end{array}$ & - & $\mathrm{H}$ and $\mathrm{NH}$ \\
\hline
\end{tabular}

${ }^{1}$ Positive (+) Neutral (0) Negative (-)

\section{Educational Programming}

The second major theme that emerged addressed the second research question: "What recommendations do stakeholders have for the college in order to achieve the college's future role?" Educational programming was defined as curriculum components including courses, degrees, schedule, quality and rigor, job training, and the development of skills as expressed in the dialogue. A dialogue analysis of educational programming indicated differences continued between communities within the service area, specifically between host-communities and non-host communities. More concerns were expressed from members 
of non-host communities regarding educational programming. This may be the result of a perception by participants of a lack of care for their community by the college personnel. One person stated, "I never get anything from the college, you cannot know what programs they have." When an interviewer asked for a clarification about a previous "breezing through" comment, the subject stated, "I mean when the college comes sometimes I've had them not sit down...they've got to get back to coach a sport."

There were also many positive comments regarding educational programming support for the college. One member of the community stated, "I know everything transfers...because my grandson last year took classes there and they transferred overall without any problems. They transferred to a school in Oklahoma." Another community member declared, "I think it's helping people get those first steps accomplished." A separate individual concurred about the value the college brings to students,

[Students] can waste their entire high school career getting ready for one thing and decide later on, maybe on something else. Therefore, with the college, that would be an instance where they really help our kids kind of expedite their career choices.

Host communities expressed mostly support for the college. "I know that [the college] enrollment's up this fall so I think, obviously, they're serving a purpose here," stated a participant. In addition, participants believed the community benefits by educating local students who become contributing members of the area. "These types of [technical] programs keep the kids here to find jobs and live in the community." There is also an appreciation for existing collaboration between the college and the school district, (e.g. the construction and welding programs).

\section{Life Skills}

As for concerns, members of the host-communities expressed minimal issues regarding the college. Most comments expressed concern for students who lack life survival basics (e.g. money management skills). "We had dropped the basics that most of us grew up with, the reading, writing, and arithmetic, and a lot of kids can actually enter college and not be able to count change." One participant stated, "We are holding [students'] hands and they don't know how to do basic money management." Frustrations permeated at times during some of the interviews. One comment aptly expressed an irritated attitude, "Any process that 
requires thinking, the [students] can't really do." Although these comments were not a reflection on the college since the students referenced were still in high school, participants indicated this pointed to a need at the college level to put basic life skill courses in place so students can acquire these skills needed.

\section{Program Expansion}

The majority of the dialogue addressing educational programming included various aspects of program expansion. From these comments, participants raised several problems. Members of non-host communities stated a lack of evening classes. Other individuals declared a need for more technical programs. "I think one of the things that we do see other community colleges doing is we're really trying to get more vocational programming because that's so important." Another interviewee stated, "In this whole area there is nothing". There was also the perception from members of a non-host community that other community colleges are trying to expand their vocational and technical programs. "I think one of the things that we do see other community colleges doing is we're really trying to get more vocational programming because that's so important to many of our students," was one observation. Several comments were made regarding the importance of vocational courses being offered in order to ensure these trades continue to be present in the community. Concerns were shared that basic trades such as plumbing, electrical, and bricklaying are dying away since programs to support them are not offered in the area. The current economy inspired one participant to share, "They're going to be hitting those community colleges in droves right now because of the retraining and the joblessness." Comments suggested a desire for vocational and technical programs with the hope of providing local students an opportunity to remain in the area upon completion of their job training.

Additional content needs suggested by interview subjects included computer technology. There seemed to be some disagreement between research participants regarding the need to teach computer technology. There was a recognized need for students to be wellequipped to use computer technology in the future; however, not everyone agreed. "Our high school kids are honestly technologically ahead of adults so I don't see that as a worry." One individual stated, "Students already know that stuff from high school, so they really need to have more advanced computer courses." Another interviewee stated technology changes 
quickly. "More importantly, if my kids go out with good attitudes and motivation and good work ethic and some character then they're going to be able to pick up whatever the technology is tomorrow or five years from now." Participants agreed that knowledge in technology will be important for the future but disagreed on where and how students needed to acquire these skills. Suggestions were made to offer a variety of technology courses in order for students to be able to take a course at the college regardless of their level of technology use.

When looking at student survey data students indicated an interest in additional programming in the fields of technology, medical, and engineering. In addition, it was evident that they had an interest in work study programs, internships, and on the job training. This would provide a hands-on opportunity to help determine their career interest. (See Table 2)

Table 2

Participants' Perceptions of Educational Programming

\begin{tabular}{llcc}
\hline \multicolumn{1}{c}{ Categories } & \multicolumn{1}{c}{ Main Aspects } & $+-0^{4}$ & Host/Non-host \\
\hline $\begin{array}{l}\text { Educational } \\
\text { Programming }\end{array}$ & A belief of a lack of care about their own community & - & $\mathrm{N}$ \\
\hline & $\begin{array}{l}\text { Frustration not having sufficient information about the } \\
\text { college }\end{array}$ & - & $\mathrm{N}$ \\
\hline & Lack of marketing & - & $\mathrm{N}$ \\
\hline Program Expansion & Lack of class flexibility & - & $\mathrm{N}$ \\
\hline & Lack of vocational/technical programs & - & $\mathrm{N}$ \\
\hline & Appreciate educational opportunities for community & + & $\mathrm{H}$ \\
\hline & Appreciate dual/concurrent credit opportunities & + & $\mathrm{H}$ and NH \\
\hline & Lack of quality of education & - & $\mathrm{N}$ \\
\hline & Lack of non-traditional offerings & - & $\mathrm{N}$ \\
\hline & Lack of job/communication skills & - & $\mathrm{H}$ and NH \\
\hline $\begin{array}{l}\text { Job Training/ } \\
\text { Vocational Skills }\end{array}$ & $\begin{array}{l}\text { Hope that job training/developing vocational skills } \\
\text { continue }\end{array}$ & 0 & $\mathrm{H}$ and NH \\
\hline Quality \& Rigor & Lack of educational quality and rigor & - & $\mathrm{H}$ and NH \\
\hline $\begin{array}{l}\text { Life } \\
\text { Skills/Communicati } \\
\text { on Skills }\end{array}$ & $\begin{array}{l}\text { Hope that life/soft skills would be taught/developed in } \\
\text { students }\end{array}$ & 0 & $\mathrm{H}$ and NH \\
\hline 4Positive $(+)$ Neutal & $(0)$ Negative (-) & \\
\hline
\end{tabular}

${ }^{4}$ Positive (+) Neutral (0) Negative (-) 


\section{Summary of Findings}

The results of this study addressed research questions regarding external stakeholders' perceptions of the value of NCCC to the service area and recommendations external stakeholders have for the college to achieve this role. Results from this study are listed below. 1. The greater the distance between the physical campuses and the service area communities, the greater number of issues raised by external stakeholders, thus diminishing the college identity.

2. Research participants living closest to the campuses felt more invited to participate in the college activities.

3. Some services received by the external stakeholders are perceived as insufficient based on their view of the role of the community college.

Each result is explained below with identity theory and invitational theory incorporated.

Result one: Identity. The greater the distance between the physical campuses and the service area communities, the greater number of issues raised by external stakeholders, thus diminishing the college identity. The phenomenon of proximity was expressed as a dichotomy of advantages and disadvantages. Many concerns were mentioned in reference to the college future role about recruitment and outreach. The more distant non-host community members stated that they did not feel valued by the college because of the little amount of time spent recruiting in their communities compared to the recruiting time spent by competing community college representatives. There was a general belief from members of non-host communities that the college did not have time to devote to visiting with students and community members. In addition, the flow and accuracy of information communicated to students and their parents located in non-host communities were insufficient regarding financial aid and admission. An organization's identity represents the collage of experiences and expectations of those who are involved with it and the various perspectives and motives brought with them. An organization's identity is important in order to recruit and retain students and bring a positive message to the community (Hatch \& Schultz, 2004). In this case, the college was perceived as falling short in helping develop a positive identity within the community. 
Result two: Sense of Invitation. Research participants living in host communities felt more invited to participate in the college classes and activities and expressed appreciation for the accessibility of the facilities and programs. Conversely, those living in non-host communities portrayed a reduced sense of invitation and therefore, felt disengaged from the community college. This lack of invitation was so great, students and their parents preferred to go elsewhere even though they paid local property taxes to the college and simultaneously paid more (out-district tuition) for similar services and education provided by other college. This is due to the fact the students did not feel invited to participate at the college. As invitational theory states, if a student does not feel there are elements of trust, respect, intentionality, and optimism present they will not have a desire to be part of the college (Schmidt, 2004).

Result three: Services offered, quality and variety of education. Some services received by the external stakeholders were perceived as insufficient based on their view of the role of the community college. Quality of education, variety of courses and programs available, and student services received by external stakeholders were perceived as lacking by research subjects residing in non-host communities. There was the perception of a reduced quality of education provided by the college; however, the perception was described as a community college phenomenon in general (Brint \& Karabel, 1989). This was recognized as having a detrimental effect on the ability to recruit students from both host and non-host communities. Some non-host community members stated concerns about the lack of course availability for people not pursuing a degree (i.e. computer courses, finance courses, or continued life time learning). The exception to these issues was dual/concurrent credit. Both host and non-host community members expressed an appreciation for dual/concurrent credit opportunities.

\section{Recommendations}

Based upon the results of the interviews and surveys, the research team would like to suggest the following recommendations:

1. Communication - Based on non-host community responses

a. Consider the individual needs of the service area communities. 
b. Seek opportunities to invite students to feel a part of the community college.

c. Increase marketing to address the lack of information, increase visibilities in the communities, and educate community members on services provided by the college.

2. Services offered, quality and variety of education
a. Consider expanding workshops and continued life-long learning courses.
b. Maintain public access of community college facilities.
c. Reconsider fee structure for non-credit/life-long learning courses.
d. Continue developing new programs for evolving career areas. 


\section{References}

Anafara, V. A., \& Mertz, N. T. (Eds.). (2006). Theoretical frameworks in qualitative research. Thousand Oaks, CA: Sage.

Badolato, V. (2010). Building community: The future of higher education may depend on the success of community colleges. Retrieved from www.jff.org/media/newswirejanuary

Benjamin, T. B. (1993). Public perception of higher education. Oxford Review of Education, 19(1), 47-63.

Brint, S., \& Karabel, J. (1989). American education, meritocratic ideology, and the legitimation of inequality: The community college and the problem of American exceptionalism. Higher Education, 18(6), 725-735.

Brubacher, J. S., \& Rudy, W. (1958). Higher education in transition: An American history. Available from http://books.google.com/books?id=0O1yXnXkWIsC\&printsec=frontcover\#PPA234 ,M1

Bureau of Labor Statistics (2009). Labor force statistics from the current population survey. Retrieved September 27, 2009, from http://www.bls.gov

Clinton, B. (1998). Text of President Clinton's 1998 state of the union address. Retrieved May 16, 2009: http://www.washingtonpost.com/wpsrv/politics/special/states/docs/sou $98 . h$ tm

Community colleges; official designation (1980). from http://kansasstatutes.lesterama.org/Chapter_71/Article_1/

Cooley, C. H. (1902). Human nature and social order. New York: Scribner's.

Cresswell, J., Plano Clark, V., Gutmann, M., \& Hanson, W. (2003). Advanced mixed methods research designs. Handbook of Mixed Methods in Social and Behavioral Research, 209-240.

The early college success story. (2010). Newswire, (62). Retrieved from www.earlycolleges.org 
Evelyn, J. (2004). Bush praises community colleges but offers few details of job-training plan. The Chronicle of Higher Education. Retrieved from http://chronicle.com/article/Bush-Praises-Community/32729/

Goffman, E. (1959). The Presentation of Self in Everyday Life. New York: Doubleday.

Hatch, M., \& Schultz, M. (Eds.). (2004). Organizational identity: A reader. New York: Oxford Press.

Lewin, T. (2009). A boon to 2-year colleges, affirming their value. New York Times. Retrieved from http://www.nytimes.com/2009/07/15/education/15college.html

Mead, G. H. (1934). Mind, Self and Society. Chicago: University of Chicago Press.

Merriam, S. B. (1998). Qualitative research and case study applications in education. San Francisco: Jossey-Bass.

National Center for Education Statistics (2007). Digest of Education Statistics, from http://nces.ed.gov/programs/digest/d08/tables/dt08 189.asp?referrer=list

Palmer, J. C. (Ed.). (2000). How community colleges can create productive collaborations with local schools. San Francisco, CA: Jossey-Bass, Inc.

Public papers of the presidents of the United States: Lyndon B. Johnson (1966). Washington, DC: Government Printing Office.

Public papers of the Presidents of the United States: Richard Nixon (1971). from http://www.presidency.ucsb.edu/ws/index.php?pid=3317\&st=\&st1=.

Purkey, W. (1992). An Introduction to invitational theory. Journal of Invitational Theory and Practice, $1(1), 5-15$.

Purvis, T. (1995). The two-year community college: Into the 21 st century. College Composition and Communication, 557-565.

Schmidt, J. J. (2004). Diversity and invitational theory and practice. Journal of Invitational Theory and Practice, 10, 27-46.

Shaw, K. M., \& Jacobs, J. A. (2003). Community colleges: New environments, new directions. Annals of the American Academy of Political and Social Science, 586, 615 . 